\title{
Vasopressin-stimulated Phosphoinositide Hydrolysis in Cultured Rat Inner Medullary Collecting Duct Cells Is Mediated by the Oxytocin Receptor
}

Isaac Teitelbaum

With the technical assistance of Alexis Strasheim

Department of Medicine, University of Colorado School of Medicine, Denver, Colorado 80262

\begin{abstract}
Studies were performed to identify the receptor that mediates AVP-stimulated phosphoinositide (PI) hydrolysis in cultured rat inner medullary collecting tubule (RIMCT) cells. While the selective $V_{1}$ receptor agonist $\left[\mathrm{Ho}^{1}, \mathrm{Phe}^{2}, \mathrm{Orn}^{8}\right]$ VT has no effect on inositol trisphosphate $\left(\mathrm{IP}_{3}\right)$ production over the range of $10^{-13}-10^{-7} M$, the selective $V_{2}$ receptor agonist VDAVP stimulates $\mathrm{IP}_{3}$ production in dose-dependent fashion. Oxytocin stimulates $\mathrm{IP}_{\mathbf{3}}$ production in dose-dependent fashion as well. AVPstimulated phospholipase $C$ activity is not inhibited by the $V_{1}$ receptor antagonist d $\left(\mathrm{CH}_{2}\right)_{5} \mathrm{Tyr}(\mathrm{Me}) \mathrm{AVP}\left(10^{-7} \mathrm{M}\right)$ but is eliminated by the $\mathrm{V}_{2}$ receptor antagonist $d\left(\mathrm{CH}_{2}\right)_{5}$ DTyr(Et)VAVP $\left(10^{-7} \mathrm{M}\right)$. Similarly, the response to oxytocin is eliminated by the $V_{2}$ receptor antagonist. The selective oxytocin receptor agonist $\left[\mathrm{Thr}^{4}, \mathbf{G l y}^{7}\right]$ oxytocin does not stimulate CAMP production in RIMCT cells but does promote PI hydrolysis. The selective oxytocin receptor antagonist desGlyNH $\mathrm{H}_{2} \mathrm{~d}\left(\mathrm{CH}_{2}\right)_{5} \mathrm{Tyr}(\mathrm{Me})-$ Thr ${ }^{4}$ JOVT $\left(10^{-7} \mathrm{M}\right)$ does not inhibit AVP-stimulated cAMP production but eliminates $\mathrm{IP}_{\mathbf{3}}$ production in response to $\mathrm{AVP}$ or the $V_{2}$ receptor agonist VDAVP. These studies demonstrate that AVP or a $V_{2}$ receptor agonist stimulate PI hydrolysis in cultured RIMCT cells via occupancy of the oxytocin receptor. (J. Clin. Invest. 1991.87:2122-2126.) Key words: vasopressin - oxytocin • phospholipase C • RIMCT cells
\end{abstract}

\section{Introduction}

In addition to its well established effect to increase cAMP, AVP has also been shown to stimulate phospholipase $C(P L C)^{1}$ and thereby increase cytosolic $\mathrm{Ca}^{2+}$ in several renal epithelia. These include the LLC-PK 1 cell (1-3), the rabbit cortical collecting duct $(4)$, and the rat inner medullary collecting duct $(5,6)$. However, the identity of the receptor responsible for mediating this effect is controversial. In one study in LLC-PK ${ }_{1}$ cells, the oxytocin receptor has been implicated (1), while in other studies elimination of the response to AVP by a $V_{1}$ receptor antagonist suggested that the AVP $V_{1}$ receptor is responsible $(2,3)$. Similar results supporting a role for the $V_{1}$ receptor have been

Address correspondence and reprint requests to Dr. Isaac Teitelbaum, C281, University of Colorado School of Medicine, 4200 East 9th Avenue, Denver, CO 80262.

Received for publication 21 January 1990 and in revised form 8 January 1991.

1. Abbreviations used in this paper: IP, inositol phosphate; PI, phosphoinositide; PLC, phospholipase C; RIMCT, rat inner medullary collecting tubule.

J. Clin. Invest.

(c) The American Society for Clinical Investigation, Inc. $0021-9738 / 91 / 06 / 2122 / 05 \quad \$ 2.00$

Volume 87, June 1991, 2122-2126 obtained in freshly isolated rabbit cortical collecting duct principal cells (4). In contrast, in the isolated perfused rat inner medullary collecting duct, a $\mathrm{Ca}^{2+}$ transient was obtained in response to the antidiuretic agonist dDAVP (5), suggesting a role for the $\mathrm{V}_{2}$ receptor. In cultured rat papillary collecting duct cells, the AVP-stimulated increase in cytosolic $\mathrm{Ca}^{2+}$ was inhibited by both an AVP $V_{2}$ and, to a lesser extent, $V_{1}$ antagonist (6). This study was therefore undertaken to define exactly which receptor is responsible for mediating AVP-stimulated PLC activity in a homogeneous population of cultured rat inner medullary collecting tubule (RIMCT) cells.

\section{Methods}

Cell culture. Cultures of RIMCT cells were prepared as previously described $(7,8)$ to yield a homogeneous population of nonintercalated cells (9). For studies on cAMP production, tissue from two rats was used to plate one 24-well Costar dish; for studies on inositol trisphosphate $\left(\mathrm{IP}_{3}\right)$ production wells were plated at three times this density to obtain uniform confluent cultures.

Determination of inositol phosphates. At $96 \mathrm{~h}$ the Hams F12/Liebovitz L15 medium in which the cells were initially grown was aspirated and the cultures washed twice with sterile PBS. The cells were then fed with inositol-free DMEM supplemented with ${ }^{3} \mathrm{H}$-myo-2-inositol (5 $\mu \mathrm{Ci} /$ well; Amersham Corp., Arlington Heights, IL). Studies were performed after $24 \mathrm{~h}$ of labeling, as this time has been demonstrated to be sufficient for incorporation into the phospholipid pool. Media was aspirated from the cells and the cells were washed twice with $500 \mu$ l of PBS. The buffer was then aspirated and replaced with $500 \mu$ l of PBS without or with the desired agonists and antagonists. The $V_{1}, V_{2}$, and oxytocin receptor agonists and antagonists employed in this study were all a generous gift from Dr. Maurice Manning (Medical College of Ohio, Toledo). Although not determined in RIMCT cells, the relative potencies of these compounds at the diuretic $\left(V_{2}\right)$, vasopressor $\left(V_{1}\right)$, and oxytocin receptors in rat tissues is shown in Table $I$. These values served as guidelines in the selection of test compounds.

Preliminary studies demonstrated that AVP-stimulated IP ${ }_{3}$ production in RIMCT cells peaks at $10 \mathrm{~s}$. Therefore, all studies were performed for $10 \mathrm{~s}$ at which time the reaction was terminated by the addition of $500 \mu \mathrm{l}$ of ice-cold $20 \%$ TCA. The cells were scraped off of the dish and centrifuged at $1,000 \mathrm{~g}$ for $10 \mathrm{~min}$. The supernate containing inositol phosphates was washed four times with an equal volume of ether and stored at $-20^{\circ} \mathrm{C}$ until analysis. Inositol phosphates were separated by anion exchange chromatography as described by Berridge et al. (15) and previously reported from this laboratory $(8,16)$. Results are expressed as $\mathrm{cpm}$ of $\mathrm{IP}_{3}$ per well.

Determination of cAMP production. Studies were performed in Krebs-Ringer's buffer, $\mathrm{pH} \mathrm{7.4,} \mathrm{at} 300 \mathrm{mOsm} / \mathrm{kg} \mathrm{H}_{2} \mathrm{O}$ in the presence of $0.5 \mathrm{mM}$ isobutylmethylxanthine to inhibit phosphodiesterase. Incubation with effector solutions and subsequent determinations of cAMP and protein were performed as reported previously $(7,9)$. Results are expressed as fmol cAMP/ $\mu \mathrm{g}$ protein.

Previous studies have demonstrated a reciprocal relationship between AVP-stimulated adenylyl cyclase (AC) and PLC activities in RIMCT cells (17). AVP stimulates AC in dose-dependent fashion; the ensuing increase in cellular cAMP content inhibits $\operatorname{PLC}(17,18)$. Con- 


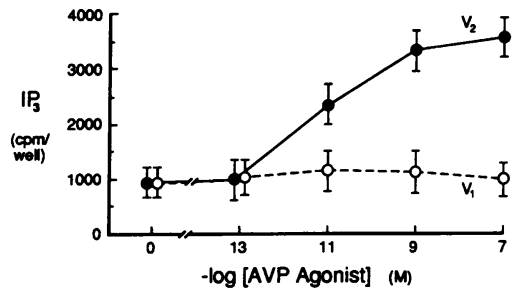

Figure 1. Dose-response curves to a $\mathrm{V}_{1}(\mathrm{O}-\cdots)$ and $\mathrm{V}_{2}(\bullet-\bullet)$ receptor agonist $(n=5)$ sequently, AVP-stimulated $\mathrm{IP}_{3}$ generation is greatest at concentrations of the peptide at which no cAMP accumulation is observed. In this study, therefore, AVP is employed at $10^{-13} \mathrm{M}$ when examining its effect on PLC and at $10^{-7}$ when examining its effect on AC.

Statistical analysis. In studies on cAMP production, values obtained in triplicate wells are meaned for an " $n$ " of one; in studies on $\mathbf{I P}_{3}$ production each well is considered an " $n$ " of one. Comparisons between two treatment groups are by the unpaired $t$ test (19). In all circumstances $P<0.05$ is considered significant. Data are presented as mean \pm SEM.

\section{Results}

Effect of $V_{1}$ and $V_{2}$ receptor agonists. The initial set of experiments examined the response to selective AVP $V_{1}$ or $V_{2}$ receptor agonists. As seen in Fig. 1 , the $\mathrm{V}_{1}$ receptor agonist $\left[\mathrm{Ho}^{1}\right.$, $\mathrm{Phe}^{2}, \mathrm{Orn}^{8}$ ] VT (Table I) does not stimulate $\mathrm{IP}_{3}$ production over the range of $10^{-13}-10^{-7} \mathrm{M}$. In contrast, a response to the $\mathrm{V}_{2}$ receptor agonist VDAVP (Table $\mathrm{I}$ ) is observed at a concentration as low as $10^{-11} \mathrm{M}(2350 \pm 370 \mathrm{cpm} /$ well vs. $940 \pm 275$, basal; $n=5, P<0.02$ ) increasing further at $10^{-9} \mathrm{M}$ with a plateau at $10^{-7} \mathrm{M}$.

Effect of $V_{1}$ and $V_{2}$ receptor antagonists. The effect of $V_{1}$ and $\mathrm{V}_{2}$ receptor antagonists is shown in Fig. 2. AVP $\left(10^{-13} \mathrm{M}\right)$ stimulates $\mathrm{IP}_{3}$ production from $699 \pm 230$ to $5748 \pm 670 \mathrm{cpm} /$ well ( $n=4, P<0.001)$. Coincubation with the $\mathrm{V}_{1}$ receptor antagonist $\mathrm{d}\left(\mathrm{CH}_{2}\right)_{5} \mathrm{Tyr}(\mathrm{Me}) \mathrm{AVP}\left(10^{-7} \mathrm{M}\right)$ (Table I) has no effect on the response to AVP $(5399 \pm 752)$. In contrast, coincubation with the $V_{2}$ receptor antagonist $d\left(\mathrm{CH}_{2}\right)_{5} \mathrm{D}$ $\operatorname{Tyr}(\mathrm{Et})$ VAVP $\left(10^{-7} \mathrm{M}\right)$ (Table I) abolishes stimulation by AVP (526 \pm 184 ; NS vs. basal). Thus, AVP-stimulated PLC activity in cultured RIMCT cells is not mediated by the $V_{1}$ receptor; it is mimicked by a $V_{2}$ receptor agonist and is inhibited by a $V_{2}$ receptor antagonist.

Effect of oxytocin. Since oxytocin had been shown to stimulate PLC in LLC-PK 1 cells (1), we next examined the ability of

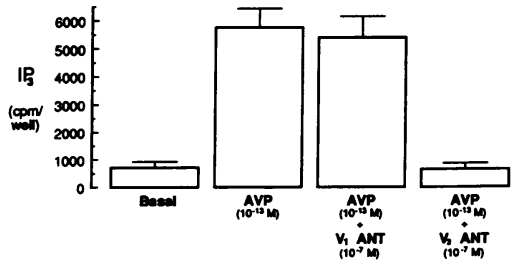

Figure 2. Effect of a $V_{1}$ and $V_{2}$ receptor antagonist on AVP-stimulated $\mathrm{IP}_{3}$ production $(n=4)$.

oxytocin to stimulate PLC in RIMCT cells. As seen in Fig. 3, a significant response to oxytocin is observed at a concentration as low as $10^{-11} \mathrm{M}(2285 \pm 392 \mathrm{cpm} /$ well vs. $940 \pm 275$, basal; $n$ $=5, P<0.05)$ and the response increases in dose-dependent fashion thereafter. To determine whether the stimulation observed in response to the $V_{2}$ receptor agonist VDAVP or oxytocin might be mediated by a common receptor, we examined the ability of the $V_{2}$ receptor antagonist to inhibit the response to oxytocin. As seen in Fig. 4, coincubation with the $V_{2}$ antagonist $\mathrm{d}\left(\mathrm{CH}_{2}\right)_{5} \mathrm{D} \mathrm{Tyr}(\mathrm{Et}) \mathrm{VAVP}\left(10^{-7} \mathrm{M}\right)$ eliminates the response to oxytocin $(4551 \pm 376$ vs. $638 \pm 213 \mathrm{cpm} /$ well; $n=4, P$ $<0.001)$. In fact, as seen in Table I, this compound actually has greater antioxytocic potency than it does antidiuretic potency. Likewise, oxytocin itself $\left(10^{-7} \mathrm{M}\right)$ cross-reacts with the $V_{2}$ receptor as it stimulates cAMP accumulation from $29.57 \pm 2.41$ to $63.64 \pm 7.33 \mathrm{fmol} / \mu \mathrm{g}$ protein $(n=5, P<0.01)$. The question then arises, which receptor mediates AVP-stimulated PLC activity in RIMCT cells, $\mathrm{V}_{2}$, or oxytocin?

Effect of a selective oxytocin receptor agonist and antagonist. To address this question, we employed a highly selective oxytocin agonist and antagonist (Table I), which unlike oxytocin, exhibit no appreciable cross-reactivity with the $V_{2}$ receptor. As seen in Fig. 5 , the selective oxytocin agonist $\left(\mathrm{Thr}^{4}, \mathrm{Gly}^{7}\right)$ oxytocin $\left(10^{-7} \mathrm{M}\right)$ (Table I) does not stimulate cAMP production in RIMCT cells $(22.10 \pm 5.04$ vs. $20.97 \pm 5.67 \mathrm{fmol} / \mu \mathrm{g}$ protein; $n=3$, NS). Similarly, the selective oxytocin receptor antagonist desGlyNH ${ }_{2} \mathrm{~d}\left(\mathrm{CH}_{2}\right)_{5}\left[\mathrm{Tyr}(\mathrm{Me}) \mathrm{Thr}^{4}\right] \mathrm{OVT}\left(10^{-7} \mathrm{M}\right)$ (Table I) does not inhibit AVP-stimulated cAMP accumulation $(337.38 \pm 34.64$ vs. $349.92 \pm 47.16 \mathrm{fmol} / \mu \mathrm{g}$ protein; $n=3, \mathrm{NS})$. Therefore, these compounds are in fact selective for the oxytocin receptor, and at the concentrations employed exhibit no activity at the $V_{2}$ receptor.

Fig. 6 depicts the dose-response curve to the selective oxytocin agonist $\left(\mathrm{Thr}^{4}, \mathrm{Gly}^{7}\right)$ oxytocin. A response is observed at a concentration as low as $10^{-11} \mathrm{M}(2143 \pm 553$ vs. $352 \pm 116 \mathrm{cpm} /$

Table I. Relative Potencies of the $V_{1}, V_{2}$, and Oxytocin Receptor Agonists and Antagonists Employed in this Study

Agonists
Compound
$\left[\mathrm{Ho}^{1}, \mathrm{Phe}^{2}, \mathrm{Orn}^{8}\right] \mathrm{VT}$
VDAVP
[Thr ${ }^{4}, \mathrm{Gly}^{7}$ ]Oxytocin
Antagonists
Compound
d( $\left.\mathrm{CH}_{2}\right)_{5} \mathrm{Tyr}(\mathrm{Me}) \mathrm{AVP}$
$\mathrm{d}\left(\mathrm{CH}_{2}\right)_{5} \mathrm{DTyr}(\mathrm{Et}) \mathrm{VAVP}$
desGlyNH $\mathrm{NH}_{2} \mathrm{~d}\left(\mathrm{CH}_{2}\right)_{5}\left[\mathrm{Tyr}(\mathrm{Me}) \mathrm{Thr}^{4}\right] \mathrm{OVT}$

\section{Diuretic \\ 0.01 \\ 17,650 \\ 0.2}

Anti-diuretic

Weak agonist

0.38

0.066
Vasopressor
1
1
1

Anti-vasopressor

1

1
Oxytocic

0.005

15

16,600

Anti-oxytocic

0.01

5.6

57.5

The activity of each compound at the $V_{1}$ receptor is arbitrarily defined as 1 . Adapted from references 10-14. 


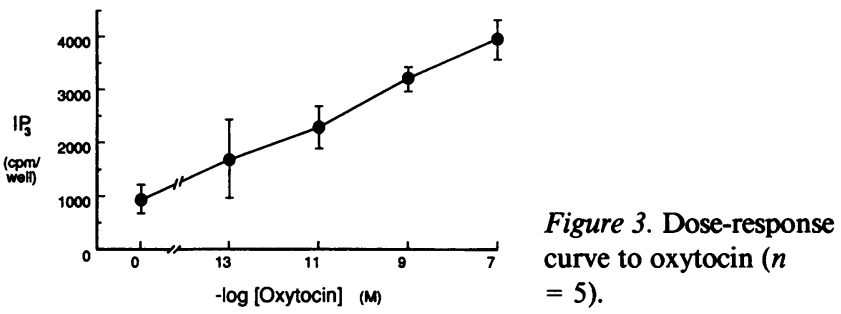

well; $n=4, P<0.02$ ) and increases dose-dependently thereafter. Coincubation with the selective oxytocin receptor antagonist $\left(10^{-7} \mathrm{M}\right)$ inhibits the response to $\left(\mathrm{Thr}^{4}, \mathrm{Gly}^{7}\right)$ oxytocin $\left(3838 \pm 715\right.$ vs. $250 \pm 122$ at $10^{-11} \mathrm{M}, P<0.005$ and $6340 \pm 597$ vs. $3702 \pm 809$ at $\left.10^{-7} \mathrm{M}, P<0.05\right)$. In contrast, the $V_{1}$ receptor antagonist $\left(10^{-7} \mathrm{M}\right)$ does not inhibit the response to $10^{-7} \mathrm{M}$ $\left(\mathrm{Thr}^{4}, \mathrm{Gly}^{7}\right)$ oxytocin $(5588 \pm 76$ vs. $5280 \pm 215 ; n=3$, NS). As seen in Fig. 7, coincubation with the selective oxytocin receptor antagonist also eliminates the response to $10^{-13} \mathrm{M}$ AVP $(4527 \pm 122$ vs. $1167 \pm 134 \mathrm{cpm} /$ well; $n=4, P<0.001)$. Similarly, as seen in Fig. 8, stimulation of PLC by the $V_{2}$ agonist VDAVP is eliminated in the presence of the oxytocin receptor antagonist. Furthermore, production of $\mathrm{IP}_{3}$ upon stimulation with $10^{-13} \mathrm{M}$ AVP $+10^{-7} \mathrm{M}\left(\mathrm{Thr}^{4}, \mathrm{Gly}^{7}\right)$ oxytocin $(7024 \pm 300$ $\mathrm{cpm} /$ well) is no greater than in response to AVP alone $(6732 \pm 270 ; n=3$, NS), indicating that the two agents act through a common receptor (Fig. 9). These data indicate that in RIMCT cells stimulation of PLC by AVP is mediated by the oxytocin receptor.

\section{Discussion}

AVP-stimulated phosphoinositide (PI) hydrolysis in hepatocytes and vascular smooth muscle cells is mediated by the AVP $V_{1}$ receptor. Indeed, it is this very property that defines the $V_{1}$ receptor (20). A priori, therefore, one would predict PI hydrolysis in response to AVP to be mediated by the $V_{1}$ receptor in other tissues, e.g., renal epithelia, as well. This has, in fact, been suggested to be the case in the LLC-PK 1 cell, a porcine renal cell line of distal tubular origin $(2,3)$ and in the rabbit cortical collecting duct (4). In RIMCT cells, however, a selective $V_{1}$ receptor agonist fails to stimulate PI hydrolysis (Fig. 1) and a selective $V_{1}$ receptor antagonist fails to eliminate the response to AVP (Fig. 2). Rather, AVP-stimulated PI hydrolysis is reproduced by a $V_{2}$ receptor agonist (Fig. 1) and is inhibited by a $V_{2}$ receptor antagonist (Fig. 2), suggesting that both adenylyl cyclase and PLC are coupled to the $V_{2}$ receptor. Although there is precedent for the notion of "receptor promiscuity", i.e., a single receptor coupling to more than one signaling system (21), the possibility that both AVP-stimulated adenylyl cyclase and PLC activities are mediated by the same receptor seems unlikely, especially as in RIMCT cells, each of these systems nega-

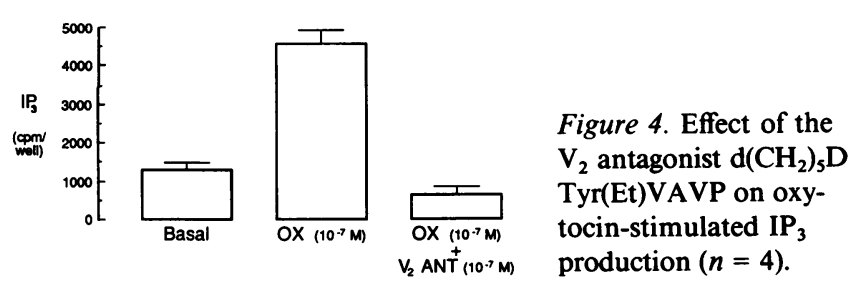

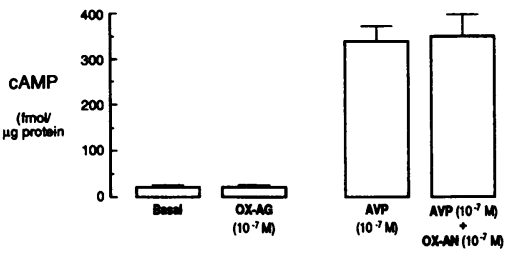

Figure 5. Effect of a highly selective oxytocin agonist $\left(\left[\mathrm{Thr}^{4}, \mathrm{Gly}^{7}\right]\right.$ oxytocin; $\left.10^{-7} \mathrm{M}\right)$ or antagonist (desG$\operatorname{lyNH}_{2} \mathrm{~d}\left(\mathrm{CH}_{2}\right)_{5}[\mathrm{Tyr}(\mathrm{Me})$ Thr ${ }^{4}$ OVT; $10^{-7} \mathrm{M}$ ) on basal and AVP-stimu-

lated cAMP accumulation, respectively $(n=3)$. Neither compound has significant activity at the $V_{2}$ receptor.

tively modulates activity of the other $(17,18)$. Because AVPstimulated PI hydrolysis in LLC-PK 1 cells has been suggested to occur via occupancy of the oxytocin receptor (1), we considered the possibility that this might be the case in RIMCT cells as well and that the effects of the $\mathrm{V}_{2}$ receptor agonist and antagonist might be a consequence of cross-reactivity with the oxytocin receptor. We found that oxytocin does indeed stimulate PI hydrolysis in RIMCT cells in dose-dependent fashion (Fig. 3) and that this response is eliminated by the $V_{2}$ receptor antagonist $\mathrm{d}\left(\mathrm{CH}_{2}\right)_{5} \mathrm{D}$ Tyr(Et)VAVP (Fig. 4), which is known to exhibit cross-reactivity with the oxytocin receptor (Table I).

Oxytocin has been reported to produce hyponatremia in humans $(22,23)$, indicating that it has activity at the $V_{2}$ receptor. Autoradiographic studies have demonstrated specific oxytocin binding sites in the papillary region of the rat kidney (24) and we have found significant stimulation of CAMP production by oxytocin in RIMCT cells (see Results). Therefore, to define whether AVP-stimulated PI hydrolysis is mediated by the $V_{2}$ or the oxytocin receptor, it was necessary that we employed a highly oxytocin-selective agonist and antagonist neither of which exhibits activity at the $V_{2}$ receptor (Fig. 5). The observations that a highly selective oxytocin agonist with no stimulatory activity at the $V_{2}$ receptor stimulates PLC (Fig. 6) and that a highly selective oxytocin antagonist that does not inhibit AVP-stimulated cAMP accumulation eliminates stimulation of PLC in response to either AVP (Fig. 7) or the $V_{2}$ agonist VDAVP (Fig. 8), clearly indicate that AVP-stimulated PI hydrolysis in RIMCT cells is mediated by the oxytocin receptor. Further support for the response to AVP being mediated by the oxytocin receptor derived from the observation that maximal AVP-stimulated $\mathrm{IP}_{3}$ production is not augmented by the addition of $10^{-7} \mathrm{M}\left(\mathrm{Thr}^{4}, \mathrm{Gly}^{7}\right)$ oxytocin (Fig. 9).

Our findings are in accord with those obtained by Stassen et

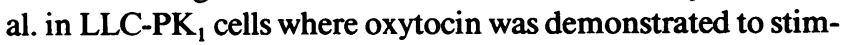
ulate PLC (1). Likewise, our findings are compatible with those previously obtained in rat inner medullary collecting ducts in which AVP-stimulated PLC activity was reported to occur in response to a $V_{2}$ receptor agonist $(5,6)$; in these studies, the possibility that the effect of the $V_{2}$ agonist might be mediated

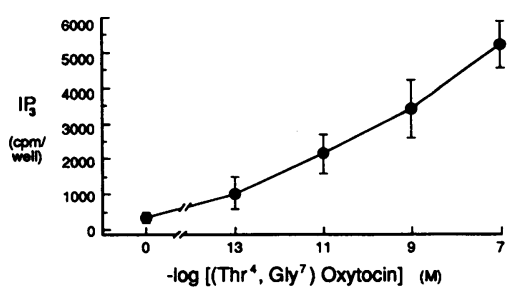

Figure 6. Dose-response curve to $\left(\mathrm{Thr}^{4}, \mathrm{Gly}^{7}\right)$ oxytocin $(n=4)$. 


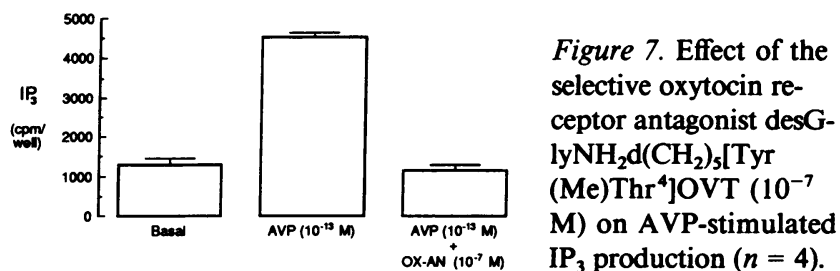

by the oxytocin receptor was not examined. In contrast, our findings differ from those of Burnatowska-Hledin and Spielman who found that the ability of AVP to cause a $\mathrm{Ca}^{2+}$ transient in both LLC-PK 1 cells (2) and rabbit cortical collecting duct principal cells (4) was inhibited by the same $V_{1}$ receptor antagonist used in this study. Similarly, in their study in LLC$\mathrm{PK}_{1}$ cells (3), Weinberg et al. were able to inhibit the response to AVP with two different $V_{1}$ antagonists and concluded that AVP-stimulated PI hydrolysis in this cell line is mediated by the $V_{1}$ receptor. While this may reflect heterogeneity of the nephron segment under study or species variation, it should be noted that in those studies the $V_{1}$ antagonists were used at concentrations $10-100$ times of that employed in this study, i.e., $10^{-6}-10^{-5} \mathrm{M}$. Each of the $\mathrm{V}_{1}$ antagonists employed has substantial antioxytocic potency as well, ranging from 1 to $35 \%$ of their antivasopressor potencies $(13,25)$. Indeed, we have found that while the $\mathrm{V}_{1}$ antagonist $\mathrm{d}\left(\mathrm{CH}_{2}\right)_{5} \mathrm{Tyr}(\mathrm{Me}) \mathrm{AVP}$ used at $10^{-7} \mathrm{M}$ does not inhibit PI hydrolysis in response to the selective oxytocin agonist $\left(\mathrm{Thr}^{4}, \mathrm{Gly}^{7}\right)$ oxytocin $(5588 \pm 76$ cpm/well, oxytocin agonist vs. $5380 \pm 215$, agonist $+V_{1}$ antagonist; $n=3$, NS), when used at concentrations of $10^{-6} \mathrm{M}$ (3372 $\pm 90 ; n=3, P<0.001$ vs. oxytocin agonist alone) or $10^{-5}$ $M(2156 \pm 307)$ it does. Similarly, while the $V_{1}$ antagonist used at $10^{-7} \mathrm{M}$ failed to inhibit AVP-stimulated PI hydrolysis (See Fig. 2) when employed at $10^{-5} \mathrm{M}$ it does $(6732 \pm 270$ vs. $3216 \pm 282 \mathrm{cpm} /$ well; $n=3, P<0.001)$. Thus, the data of Burnatowska-Hledin and Spielman $(2,4)$ and of Weinberg et al. (3) may also reflect AVP-stimulated PI hydrolysis being mediated by the oxytocin receptor. On the basis of our findings that $(a)$ at sufficiently high concentrations either the $V_{1}$ or the $V_{2}$ receptor antagonist cross-reacts with the oxytocin receptor; $(b)$ the response to AVP is eliminated by large concentrations of either the $V_{1}$ or the $V_{2}$ antagonist; (c) a selective $V_{1}$ agonist does not stimulate PI hydrolysis in dose-dependent fashion, whereas $(d)$ a highly selective oxytocin agonist does; and (e) AVP-stimulated PI hydrolysis is eliminated by a highly selective oxytocin antagonist, we conclude that it is, in fact, the oxytocin receptor that mediates AVP-stimulated phosphoinositide hydrolysis in RIMCT cells and probably throughout the distal mammalian nephron. It should be noted, however, that as these studies were performed in cultured cells, further studies will be required to determine whether oxytocin promotes an increase in cytosolic calcium in the inner medullary collecting duct in vivo.

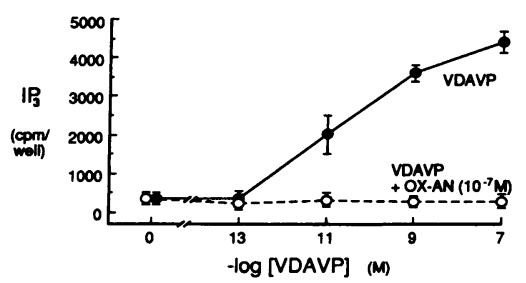

Figure 8. Effect of desGlyNH ${ }_{2} \mathrm{~d}\left(\mathrm{CH}_{2}\right)_{5}[\mathrm{Tyr}$ (Me) Thr ${ }^{4}$ OVT $\left(10^{-7}\right.$ M) on VDAVP-stimulated $\mathrm{IP}_{3}$ production $(n$ $=3$ ).

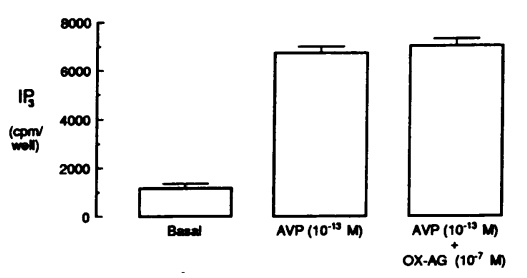

Figure 9. Effect of the selective oxytocin agonist $\left(\mathrm{Thr}^{4}, \mathrm{Gly}^{7}\right)$ oxytocin on AVP-stimulated $\mathrm{IP}_{3}$ production $(n=3)$. Addition of the oxytocin agonist does not augment the response to AVP.

Maneuvers that stimulate AVP release from the posterior pituitary (e.g., hemorrhage, increased plasma osmolality, or the intraventricular administration of carbachol or angiotensin II) result in increased plasma oxytocin levels as well (26-28). Whether, in normal physiology, the oxytocin receptor in the mammalian kidney is occupied by oxytocin or by the related neuropeptide, AVP is uncertain. It is clear that occupancy of the receptor results in stimulation of PLC and hydrolysis of PI. The role of AVP- or oxytocin-stimulated PI hydrolysis in modulating the hydroosmotic response to AVP is uncertain. One of the consequences of PI hydrolysis is activation of protein kinase $\mathrm{C}$ which inhibits the hydroosmotic response to AVP both pre- and post-cAMP $(18,29,30)$. This suggests that stimulation of PLC by AVP might be involved in turning off the hydroosmotic response. Alternatively, generation of $\mathrm{IP}_{3}$ with a subsequent increase in cytosolic $\mathrm{Ca}^{2+}$ might be necessary for the development of the hydroosmotic responses. Preliminary data reported by Leite et al. support this possibility, as they observed no hydroosmotic response to AVP when cytosolic $\mathrm{Ca}^{2+}$ was chelated with TMB-8 (31). Lastly, one must consider the possibility that oxytocin receptor-stimulated PI hydrolysis mediates the natriuretic response to oxytocin $(32,33)$ but plays no role in modulation of the hydroosmotic response to AVP. Further studies will be required to define the physiologic role of AVPstimulated PI hydrolysis that is mediated via the oxytocin receptor.

\section{Acknowledgments}

The authors wish to thank Ms. Linda M. Benson for secretarial assistance.

This work was supported by a grant from the National Institutes of Health (DK-38464).

\section{References}

I. Stassen, F. L., G. Heckman, D. Schmidt, M. T. Papadopoulos, P. Nambi, H. Sarau, N. Aiyar, M. Gellai, and L. Kinter. 1987. Oxytocin induces a transient increase in cytosolic free $\left[\mathrm{Ca}^{2+}\right]$ in renal tubular epithelial cells: evidence for oxytocin receptors on LLC-PK1 cells. Mol. Pharmacol. 33:218-224.

2. Burnatowska-Hledin, M. A., and W. S. Spielman. 1987. Vasopressin increases cytosolic free calcium in LLC-PK $\mathrm{P}_{1}$ cells through a $\mathrm{V}_{1}$-receptor. Am. J. Physiol. 253:F328-F332.

3. Weinberg, J. M., J. A. Davis, J. A. Shayman, and P. R. Knight. 1989 Alterations of cytosolic calcium in LLC-PK, cells induced by vasopressin and exogenous purines. Am. J. Physiol. 256:C967-C976.

4. Burnatowska-Hledin, M. A., and W. S. Spielman. 1989. Vasopressin V, receptors on the principal cells of the rabbit cortical collecting tubule. J. Clin. Invest. 83:84-89.

5. Star, R. A., H. Nonoguchi, R. Balaban, and M. A. Knepper. 1988. Calcium and cyclic adenosine monophosphate as second messengers for vasopressin in the rat inner medullary collecting duct. J. Clin. Invest. 81:1879-1888.

6. Ishikawa, S., K. Okada, and T. Saito. 1988. Arginine vasopressin increases cellular free calcium concentration and adenosine $3^{\prime}, 5^{\prime}$-monophosphate production in rat renal papillary collecting tubule cells in culture. Endocrinology. 123:1376-1384.

7. Teitelbaum, I, and T. Berl. 1986. Effects of calcium on vasopressin-me- 
diated cyclic adenosine monophosphate formation in cultured rat inner medullary collecting tubule cells. J. Clin. Invest. 77:1574-1583.

8. Teitelbaum, I, A. Strasheim, and T. Berl. 1990. Epidermal growth factorstimulated phosphoinositide hydrolysis in rat inner medullary collecting tubule cells: Regulation by $\mathrm{G}$ protein, calcium, and protein kinase C. J. Clin. Invest. 85:1044-1050.

9. Teitelbaum, I., A. Strasheim, and T. Berl. 1989. Adrenergic control of cAMP generation in rat inner medullary collecting tubule cells. Kidney Int. 35:647-653.

10. Sawyer, W. H., M. Acosta, L. Balaspiri, J. Judd, and M. Manning. 1974. Structural changes in the arginine vasopressin molecule that enhance antidiuretic activity and specificity. Endocrinology. 94:1106-1115.

11. Lowbridge, J., and M. Manning. 1977. Synthesis and some pharmacological properties of [4-Threonine, 7-glycine] oxytocin, [1-(L-2-Hydroxy-3-mercaptopropanoic acid), 4-threonine, 7-glycine]oxytocin (Hydroxy[ $\left.\mathrm{Thr}^{4}, \mathrm{Gly}^{7}\right]$ oxytocin), and [7-Glycine]oxytocin, peptides with high oxytocic-antidiuretic selectivity. $J$. Med. Chem. 20:120-123.

12. Manning, M., A. Olma, W. A. Klis, and A. M. Kolodziejczyk. 1982. Design of more potent antagonists of the antidiuretic responses to arginine vasopressin. J. Med. Chem. 25:45-50.

13. Manning, M., and W. H. Sawyer. 1985. Development of selective agonists and antagonists of vasopressin and oxytocin. In Vasopressin. R. W. Schrier, editor. Raven Press, Ltd. New York. 131-144.

14. Manning, M., M. Kruszynski, K. Bankowski, A. Olma, B. Lammek, L. L. Cheng, W. A. Klis, J. Seto, J. Haldar, and W. H. Sawyer. 1989. Solid-phase synthesis of 16 potent (selective and nonselective) in vivo antagonists of oxytocin. J. Med. Chem. 32:382-391.

15. Berridge, M. J., R. M. C. Dawson, C. P. Downes, J. P. Heslop, and R. F. Irvine. 1983. Changes in the levels of inositol phosphates after agonist-dependent hydrolysis of membrane phosphoinositides. Biochem. J. 212:473-482.

16. Teitelbaum, I. 1990. The epidermal growth factor receptor is coupled to a phospholipase $A_{2}$-specific pertussis toxin-inhibitable guanine nucleotide-binding regulatory protein in cultured rat inner medullary collecting tubule cells. J. Biol. Chem. 265:4218-4222.

17. Teitelbaum, I., and A. Strasheim. 1990. AVP stimulates adenylyl cyclase and phospholipase $\mathrm{C}$ in reciprocal fashion in cultured RIMCT cells. Am. J. Physiol. 259:C693-C696.

18. Teitelbaum, I. 1990. Cyclic AMP and diacylglycerol. Mutually inhibitory second messengers in cultured rat inner medullary collecting duct cells. $J$. Clin. Invest., 86:46-51.

19. Snedecor, G. W., and W. G. Cochran, editors. 1980. Statistical Methods. 7th ed. Iowa State University Press, Ames, IA. 224-226.
20. Michell, R. H., C. J. Kirk, and M. M. Billah. 1979. Hormonal stimulation of phosphatidylinositol breakdown, with particular reference to the hepatic effects of vasopressin. Biochem. Soc. Trans. 7:861-865.

21. Cerione, R. A., C. Staniszewski, J. L. Benovic, R. J. Lefkowitz, and M. G. Caron. 1985. Specificity of the functional interactions of the $\beta$-adrenergic receptor and rhodopsin with guanine nucleotide regulatory proteins reconstituted in phospholipid vesicles. J. Biol. Chem. 260:1493-1500.

22. Schwartz, R. H., and R. W. A. Jones. 1978. Transplacental hyponatraemia due to oxytocin. Br. Med. J. 1:152-153.

23. Feeney, J. J. 1982. Water intoxication and oxytociǹ. Br. Med. J. 285:243.

24. Tribollet, E., C. Barberis, J.-J. Dreifuss, and S. Jard. 1988. Autoradiographic localization of vasopressin and oxytocin binding sites in rat kidney. Kidney Int. 33:959-965.

25. Manning, M., B. Lammek, K. Bankowski, J. Seto, and W. H. Sawyer. 1985. Synthesis and some pharmacological properties of 18 potent O-alkyltyrosine-substituted antagonists of the vasopressor responses to arginine vasopressin J. Med. Chem. 28:1485-1491.

26. Brimble, M. J., R. E. J. Dyball, and M. L. Forsling. 1978. Oxytocin release following osmotic activation of oxytocin neurones in the paraventricular and supraoptic nuclei. J. Physiol. 278:69-78.

27. Weitzman, R. E, T. H. Glatz, and D. A. Fisher. 1978. The effect of hemorrhage and hypertonic saline upon plasma oxytocin and arginine vasopressin in conscious dogs. Endocrinology. 103:2154-2160.

28. Hashimoto, H., T. Noto, and T. Nakajima. 1988. A study on the release mechanism of vasopressin and oxytocin. Neuropeptides. 12:199-206.

29. Schlondorff, D., and S. D. Levine. 1985. Inhibition of vasopressin-stimulated water flow in toad bladder by phorbol myristate acetate, dioctanoylglycerol, and RHC-80267. J. Clin. Invest. 76:1071-1078.

30. Ando, Y., H. R. Jacobson, and M. D. Breyer. 1987. Phorbol myristate acetate, dioctanoylglycerol, and phosphatidic acid inhibit the hydroosmotic effect of vasopressin on rabbit cortical collecting tubule. J. Clin. Invest. 80:590-593.

31. Leite, M., Jr., and W. N. Suki. 1989. TMB-8 inhibits the initiation phase but not the sustained phase of AVP and dDAVP-activated hydroosmotic effect in rabbit cortical collecting tubules. Clin. Res. 37:613a. (Abstr.).

32. Balment, R. J., M. J. Brimble, M. L. Forsling, and C. T. Musabayane. 1986. The influence of neurohypophysial hormones on renal function in the acutely hypophysectomized rat. J. Physiol. 381:439-452.

33. Conrad, K. P., M. Gellai, W. G. North, and H. Valtin. 1986. Influence of oxytocin on renal hemodynamics and electrolyte and water excretion. Am. J. Physiol. 251:F290-F296. 